\title{
The Impact of Tayub Exploitation on The Tradition and Life of Javanese Society
}

\author{
${ }^{\otimes}$ Noordiana $^{1}$, Anik Juwariyah ${ }^{1}$, Fithriyah Inda ${ }^{2}$ \\ ${ }^{1}$ Department of Drama, Dance and Music, Faculty of Language and Art, \\ Universitas Negeri Surabaya, Indonesia \\ ${ }^{2}$ Department of English, Faculty of Language and Art, \\ Universitas Negeri Surabaya, Indonesia \\ Jl. Ketintang Baru XII No. 34, Ketintang, Gayungan, Surabaya, Jawa Timur 60231 \\ 区E-mail: noordiana131@gmail.com
}

Received: October 19, 2016. Revised: November 12, 2016. Accepted: December 11, 2016

\begin{abstract}
This study is aiming at finding out the impact of Tayub exploitation on the tradition and life of Javanese society. Research approach implemented in this study was qualitative. In addition, the research technique employed was interview, observation, documentation, and literary study. Results show that the new form of Tayub diminishes the structure of feminism, neglects simplicity, gentleness and spontaneity that are supposed to be part of Tayub dance. The movement of dance, music, and costume are also changed into a total different form, compared with the genuine version of Tayub dance. These major changes do not only bring negative impacts on the dance structure, but also change the society's mindset and behavior. People living in the countryside part of Java have lost their control towards customs' regulation and a philosophy that used to be held tightly by them.
\end{abstract}

Keywords: tayub exploitation; tradition; Javanese society

How to Cite: Noordiana., Juwariyah, A. \& Inda, F. (2016). The Impact of Tayub Exploitation on The Tradition and Life of Javanese Society. Harmonia: Journal of Arts Research and Education, 16(2), 133-142. doi:http://dx.doi.org/10.15294/ harmonia.v16i2.7514

\section{INTRODUCTION}

Tayub as a performing art is a traditional art that has a strong tradition rooted in the life of Javanese society, therefore, the forms, procedures, and compositions of Tayub dance still tightly hold the custom and culture of Javanese society life. Pradhana (2013, p. 198) emphasizes that in traditional art value of customs and beliefs have become one aspect that merges and takes part in the life of the involved society. Therefore, all behaviour, law, and culture that are developed are not separated from the influence of tradition and myth had by the society. The belief of ani- mism which contains the aspect of myth and magic becomes an essential factor in the tradition of Tayub dance. Suharto $(1999$, p. 15) states that during the first days of Tayub, the dance is used as a ritual to worship the goddess of farming fertility. Performing Tayub is believed to have magic power. Even, it was believed that the more erotic the dance is, the more blessings and fertility they will get. The myth and tradition attached in the dance packaging has succesfully driven the dance itself to be a legendary folk art that is admired by the society, especially the ones who live in the countryside.

Tayub has become a certain power 
had by society and be a part of the breath of the people living in it. Therefore, changing made to this folk art brings severe influence of the mentality and culture of the involved society. Results of the field study tell that there is modernization in a form of a new system and procedure that has diminished the purity of this art by abolishing the element of tradition, that makes the art tarnished and is slowly leaving by the society (Data from The Division of Art, Department of Culture Yogyakarta, 2008). The modernization which brings new colour into the art has changed the essence of the performance into a more monotonous and boring art. The essence of the performance has changed into more systematic and simple form that makes the dance losing the element of magic and eroticism. Losing these elements also let the dance to lose its art and unique sides. As a result, the Tayub performance nowadays only aims to entertain and sometimes as political propaganda (Juwariah, 2013).

The element of art and the essence of dance slowly disappear. In the end, its identity is lost in diplomatic and modernity rules which has been successfully ruined the natural element of Tayub performing art. This phenomenon gets more severe by the swift purpose of Tayub, as a traditional custom at first into an entertainment medium in the end. Even, the intervention of government through regional conduct number 25 in 2000 and number 26 in 2005 regulating the limitation of performing art staging even more ruining the mental and cultural enrichment in the description areas. Research conducted in the center of Tayub performing art showed concrete data on how modernization that infiltrates the existence of this traditional art has changed the face and essence of this folk art (Widyastutieningrum, 2007). These impacts do not stop at the point of structure and physical material of this art, but also has given deep impact towards the culture and mentality of the involved society.

Tayub as a performing art is one of the art form that is considerably popular in Javanese society. The list below is rese- arched and studies which have received much attention from academicians and researchers, namely:

The Comparison Study of Langen Tayub Performing Art in several Cultural Ethnics in East Java. This study found that in several research sites, there were different ways of naming the Langen Tayub performer, the model of costume the dancers worn, as well as the songs sang as the music accompaniment.

Singing and Silences: Transformations of Power through Javanese Seduction Scenarios. This work discussed about the life of Javanese traditional singers (sinden) in the context of social status hierarchy in the local Javanese society; how a traditional song singer uses their feminism power to support their patriarchal status in Javanese culture.

Tohari's Trilogy: Passages of Power and Time in Java. This study discussed Javanese culture from the perspective of history and gender. How modernity and Javanese tradition are accumulated in President Soeharto's very long ruling era, as well as how the gender equality role existed in the patriarchal tradition in Javanese society.

Tayub as a folk art in globalization era (A study about the impact of globalisation towards Tayub as a performing art in Special Region of Yogyakarta). This study discusses in very detail about the distribution of Tayub as a performing art in Special Region of Yogyakarta before and after the globalization. This study also explored the function and the performing form of Tayub in the globalization era in Special Region of Yogyakarta.

Discovering Local Wisdom in the Novel entitled Ronggeng Dukuh Paruk by Ahmad Tohari. This study analyzed the style of language used by Tohari to discover the values of Javanese culture's local wisdom as an identity maker of Indonesia. Eventhough this study does not discuss Tayub in particular, however, the study about rethorical language that is able to exploit, manipulate, and make use of all language potencial can provide a signifi- 
cant illustration towards the tradition of Javanese culture in its relation to the ritual and tradition of Tayub performance.

Repertoire in Ronggeng Dukuh Paruk by Ahmad Tohari as an Aesthetic Study of Wofgang Iser. This study described the relation of facts and fiction that has become a serious discussion in literary study. This study aims at providing an actual illustration on feudal culture and passive mental attitude as well as art politics during the deceased of the New Order regime.

The function of Tayub Performing Art for People living in Dusun Ngrajek Desa Sambirejo Kecamatan Tanjung Anom Kabupaten Nganjuk. This study discussed the Tayub performing art from the perspective of local peoples' culture.

The Popularity of Waranggana Tayub Malang through Body Exploitation. This study examined the position and role of Tayub dancers in Tayuban tradition in Malang as well as the existence of The Javanese traditional song singers. The results of the study concerned about how a singer used her body both in the context of performing art and in its relation to the local people.

The representation of Ronggeng in Three different Indonesian Novel. This work discussed the figure of Ronggeng that is represented in three different novels, i.e. "Ronggeng Dukuh Paruk" by Ahmad Tohari, "Ronggeng" by Dewi Lingga Sari, and "Karti Kledek Ngrajek" by S.W. Warsito. This study gave an illustration that ronggeng as an artifact of local culture is a reflection of society forming it. The gegraphical condition, tradition, and local custom, also the society's mindset have a significant role in the performing art tradition of Ronggeng.

The value of Javanese culture in novel entitled Ronggeng Dukuh Paruk by Ahmad Tohari. This study focused on the value of Javanese cultural value in three aspects of problems, they are, how the relationship of human and God illustrates the Javanese cultural value, how the relationship between humans illustrates the value of Javanese culture, and how the relationship between human and nature illustrates the value of Javanese culture. These three aspects are interrelated with the essence of Javanese culture which honors nature, belief and relations between people. Therefore, the ritual of Tayub that is presented with animism belief also gives an actual message on the attachment of this performing art with the Javanese culture.

\section{METHOD}

Approach implemented in this study was descriptive qualitative since this study result provides careful picture related to certain individual or groups in its relation to the meaning shift of Tayub as performing art on tradition and the life of the involved society.

Research was taken place in Yogyakarta, especially in Semin district Gunung Kidul regency. This site became the study focus since it was the source of Tayub performing art. Tayub in this place is still popular and is often performed on stage. Besides, the government's hegemony in exploiting the performance is considerably high.

The main data source of this study was trilogy novel by Ahmad Tohari entitled "Ronggeng Dukuh Paruk", "Lintang Kemukus Dini Hari", and "Jentera Bianglala". Besides, this study also derived the data from Tayub artists, public figures, and the board members of Tayub organization.

The data collection technique in this study were interview, observation, documentation, and literary study. In-depth interview was applied to Tayub artists, public figures, and board members of Tayub organization.

\section{RESULTS AND DISCUSSION}

Exploitation towards Tayub as a performing art also gives impact to the life of Javanese society. Tayub which was initially held for custom with a fix ritual tradition has changed its direction and developed to be simpler in pattern, systematic, and 
very different ritual tradition compared to one existed in the past. At the beginning, Tayub as a performing art had purpose as an expression of gratitude to God, i.e. a fertile soil, a satisfying harvest, or at least a symbol and expression of happiness. Therefore, the elements of magic and religion are always present in every Tayub's performance. The locations used for Tayub performance are also chosen carefully, such as: grave yard, sacred tomb, or other sacred places.

...rombongan ronggeng bergerak menuju pekuburan Dukuh Paruk. Kartareja berjalan paling depan membawa pedupaan. Srintil di belakangnya. Menyusul para penabuh. Sakum dituntun oleh seorang penabuh lainnya. Di belakang mereka menyusul segenap warga Dukuh Paruk, dari anak-anak sampai yang tua-tua. Sampai di tujuan, Kartareja meletakkan pedupaan di ambang pintu cungkup leluhur Dukuh Paruk. Mantera-mantera dibacakan oleh Nyai Kartareja, ditiupkan ke ubun-ubun Srintil. Kemudian ronggeng itu dituntun ke depan pintu cungkup. Disana Srintil menyembah dengan takjim, lalu bangkit dan berjalan ke hadapan lingkaran para penabuh. Kelengangan pekuburan Dukuh Paruk pecah. Suara gendang dan calung menggema bersama dalam irama khas. Pada saat seperti itu orang-orang Dukuh Paruk percaya semua roh di pekuburan itu bangkit melihat pertunjukan (Ronggeng Dukuh Paruk, 1992, p. 41-42).

Tayub performance is not only presented as a dance, but more to have a strong essence of tradition, myth, and belief of ancestors. From the previous citation, it is told how Srintil who was a dancer is admired by people from Dukuh Paruk. She started her first performance in the Dukuh Paruh cemetery in a fixed ritual and tradition, comprising all the spell which is delivered and insist that is burned before the performance, and not to mention the people accompanying her to the stage who walk in a fixed order.

This concept is related closely to the agrarian life of Javanese' countryside so- ciety who still hold the belief to the ancestors tightly. Farming community tends to have traditional life pattern and mindset. This community emphasis a calm, peace, and happy life. The religion they hold is close with the belief of animism, dynamism, and myth that show the conformity between human and nature (Minsarwati, 2002). Therefore, Javanese villagers are holding tightly all traditions, myths, and beliefs as part of their life.

"Ia eksis dengan segala sumpah serapah cabul, kepercayaan pada mistik dan takhyul, norma-norma seksual yang longgar serta kemelaratan abadi. Terpencil dari segala hiruk-pikuk kota besar, orang-orang Dukuh Paruk adalah manusia-manusia lugu yang percaya pada pengaturan alam. Percaya pada karma. Percaya bahwa segala sesuatu di dunia ini berpasang-pasangan, berkebalikan. Kesenangan berpasangan dengan kesedihan. Terang dengan gelap. Malam dengan siang" (Ronggeng Dukuh Paruk, 1992, p. 107).

Citation taken from novel entitled "Ronggeng Dukuh Paruk" by Ahmad Tohari above clearly illustrates situation of rural life that reflects the thinking pattern of rural Javanese society or the villagers. The villagers believe in mystical belief, natural rule, and karma.

In addition to this it the traditional Javanese society believes in the spirit of ancestor, offering, worship, and other mystical religious elements. The same as this is the Tayub. It is also packaged with this kind of traditional belief, that Tayub performance has to follow the fixed rules and tradition, and that violating it means harm. It is shown in the following citation.

Waktu itu kita disebut sebagai kelompok seniman rakyat. Padahal kita tidak pernah mengumumkan nama apa pun. Kemudian ada satu kejadian, aku dilarang membakar kemenyan dan memasang sesaji. ... "Itulah. Yang jelas hal semacam ini baru sekarang kita alami. Sejak dulu ronggeng ya ronggeng. Tidak harus pakai nama atau papan nama. $\mathrm{Du}-$ 
kuh Paruk sejak dulu ya Dukuh Paruk. Tanpa gambar partai di mulut jalan itu pun pedukuhan kita ini bernama Dukuh Paruk. Nah, Kartareja. Bagaimana ini?" Kartareja diam.

"Dan ini," sambung Sakarya. "Bagaimana kalau kita selalu dilarang memasang sesaji! Ini pelanggaran adat yang bukan main. Kartareja, aku amat takut menerima akibatnya." (Lintang Kemukus Dini Hari, 1988, p. 151)

Javanese society is very obedient with the ancestor tradition. It is shown from the citation that the villagers believe that a disaster will happen if the rules are violated. Therefore, Sakarya and Kertaraja as the respected elders of Dukuh Paruh feels worry when many rules and procedures in performing Tayub are violated.

Perasaan kakek Srintil itu lebih dirisaukan oleh peristiwa-peristiwa kecil namun baginya penuh makna. Kemarin, seekor burung tlimukan terbang secepat angin menerobos pintu rumahnya yang terbuka, membentur keras cermin lemari kacanya. Burung itu runtuh ke lantai dan mati seketika. Dari paruhnya yang mungil merah menetes darah. Entah mengapa Sakarya sangat terkesan oleh pemandangan itu; seekor burung yang molek dengan bulu hijau mengkilap dan paruh seperti cabai masak, mati di hadapannya dengan gelimang darah. Sehari sebelumnya kamitua Dukuh Paruk itu menyaksikan seekor ayam hutan hinggap di pohon angsana di samping rumahnya. Sakarya selalu membaca sasmita alam. Sakarya tidak pernah berpikir bahwa suatu perkara sekecil apa pun bisa berdiri sendiri, lepas dari kehendak semesta. Dan semuanya pastilah mengemban makna yang sasmita. Sepanjang menyangkut binatang asing yang mendekat, apalagi sampai masuk ke rumah, siapa pun di Dukuh Paruk akan membacanya sebagai pertanda (Lintang Kemukus Dini Hari, 1988, p. 165).

An ancient belief teaches Javanese society to read the signs. All events and incidents happened in this world are signs. Several incidents happened after the change of ritual in the performance of Tayub can be felt by Sakarya, the grandfather of Srintil. Therefore, he does not agree to change. Sakarya is worried about bad things that will happen if the Tayub performance is not held based on the fixed ritual rules and procedures.

For traditional Javanese society, belief to the ancestors must be kept tight. Violating the rules means to create bad things and reduce windfall or fame. From the interview 1, it was understood that Mbah Gunem (a Tayub dancer from the 1960s) also followed several rituals or fixed rules from her ancestor. There were certain rules and rituals that must be done for the Tayub performance to run well. Even, a field study mentions that in the more remote rural are around Semin district, several rituals are still followed to make sure that the Tayub performance runs well.

Exploitation done to the Tayub art certainly brings impact to the life of rural Javanese society, not only from the perspective of dance but also from the local people's thought. Exploitation done to the Tayub dance has inferred modernity and made the dance becoming simpler, more entertaining and amusing. As a result, this art has changed into a shallow performance, and given more orientation to the pleasure, then slowly leaves the tradition formed by the ancestors. Soekanto (1994, p. 332) states that modernization is able to shift the interrelated value and culture within the society. Social change is interrelated to the culture shift; when a social change takes place, then a cultural change will be there too, and vice versa. Thus, the emerging of modernization has given new colour on Tayub dance and certainly has given an impact to the local people' sociocultural value.

"Meski dalam wawasan yang sederhana Srintil merasa pentas ronggeng dalam rapat-rapat itu sekedar pelengkap. Memang meriah, tetapi lain. Gempita tetapi kering makna. Apalagi dengan lirik tembang yang sudah banyak diubah. Penonton selalu dalam keberingasan yang tidak bisa dimengerti dan karenanya 
Srintil kadang merasa ngeri. Bahkan Sakum yang buta dua belah mata ikut mewarnai perubahan yang dirasakan Srintil. Penabuh calung itu kehilangan dirinya; kekocakan spontan yang selalu tepat ketika ronggeng menggoyang pinggulnya. Sakum, dengan kepekaan dan kehalusan perasaannya mampu menangkap keringnya pentas ronggeng yang digelar bersama rapat-rapat propaganda itu" (Lintang Kemukus Dini Hari, 1988, p. 154).

In the citation, it can be seen that there are some elements of modernization that gets into the Tayub performance. Lyrics of the songs as the music accompaniment are changed, the sound of Gendang and Calung is also changed. The nuance of the performance has lost its "sense" and changed into festivity. The Tayub performance only acts as the complement and is not existed as the main element of a ritual.

The Tayub performing art in this modern era has become only a compliment in a certain occasion. Its independent and dominant existence as the main element of a custom ceremony and local art has shifted into an entertaining dance as a part of national art. Therefore, Tayub as the main element of rural Javanese society performing art has shifted into an entertainment that only completes the rural society that has changed into a more modern and dynamic living. The concept of "Nrimo ing Pandum" has slowly disappeared form the life of rural Javanese society. Modernization makes everything worth a pay and respected with money. Doing something sincerely has slowly disappeared from the natural character of rural Javanese society. This identity is replaced with egocentric and materialism. Javanese philosophy that is based on the ancestor's taught only act as a complement and past history.

Boleh jadi hanya Sakarya yang tidak sepenuhnya larut dalam kegembiraan. Sikapnya yang hati-hati berasal dari filsafatnya yang sederhana. Bagiya segala sesuatu berpasang-pasangan adanya, tak terkecuali sesuatu yang bernama kegembiraan. Pasangannya pastilah kesusahan. Sepanjang lintasan hidupnya yang panjang Sakarya sering menemukan kenyataan bahwa segala sesuatu tak pernah berpisah jauh dari pasangannya. Orang selalu memilih pihak yang menguntungkan dan menjauhi pihak yang merugikan. Antara keduanya harus tetap terjaga jarak. Dan dalam pikiran Sakarya menjaga jarak itu berarti harus selalu bersikap hati-hati, eling. Kadang juga diartikannya sebagai keseimbangan dan tidak berlebih-lebihan(Lintang Kemukus Dini Hari, 1988, p. 89)

It is told in the above citation that even if the elders (represented by Sakarya) still hold the Javanese tradition tightly, however, most of the society has been affected by modernization and has forgotten the precious ancestor's teachings. It has left the Javanese philosophy and followed the world's modernization.

\footnotetext{
“Dan ronggeng Dukuh Paruk itu," ujarnya dengan tekanan kata yang istimewa, "mereka adalah seniman-seniman rakyat! Rakyat yang perkasa, rakyat yang demikian tangguh, schingga mereka masih tetap menyanyi dan menari meskipun telah berabad-abad hidup tertindas. Sebentar lagi Srintil dan kawan-kawannya akan tampil di pentas ini. Tetapi jangan salah. Apa pun yang disajikannya tidak bisa lain daripada sebuah makna tuntutan kebebasan! Bebas dari penindasan kaum imperialis, kapitalis, dan kolonialis bersama antek-antek mereka. Sekali lagi, bebas!"(Lintang Kemukus Dini Hari, 1988, p. 99)
}

In the above citation, we can see that the society living in Dukuh Paruk has changed into a "stronger" society and their art, that is Tayub, has changed into a free and independent performance from any chains that previously tied them.

This change has created Tayub dance into a smarter and more systemic type of dance, but losing its virginity, spontaneity, and flexibility. Tayub dancers are presented in a more equal position with the man who is dancing them has actually 
shown the existence of gender equality that erasing the meaning of woman from a Javanese patriarchy perspective that tends to be more inferior. Kemben, Tayub's costume in its genuine version, has been changed into various models of Kebaya. Jarik worn by the dancers are made wider, that will ease the dancers to move. The performance of the dance itself does not need to be held for a whole night, does not need to have certain ceremonial purposes, but more of a short time performance that aims to only entertain the audiences. This is caused by modernization that has changed rural Javanese society into a more modern human being who are more established, and finally caused the traditional cultures to be slowly disappear. The era of industry and modernization has also changed the rural Javanese society to be more economical. The irrigation system is built to maximize harvest. Factories are built throughout the countryside to maximize the economy acceleration. Therefore, it considers normal to understand the reason behind the shift of tradition in performing Tayub. This art does not emphasize its existence to be a ritual dance, but more to be an entertaining show. Even though in some areas, Tayub is still used to hold a custom ritual ceremony, however, the procedures in having the dance are more flexible if it is compared with earlier era when this performing art was first shown.

Tayub as a performing art cannot be separated from the life of Javanese society, especially one who lives in rural or countryside area. This art has become one special part of society's life and will keep developing in line with the developing era. Tayub was first used as an intercommunication dance to celebrate a village's thanksgiving ceremony or other village rituals. However, during its development, Tayub is changed into an entertaining dance to amuse the society living in that particular area. The novel entitled Ronggeng Dukuh Paruk by Akhmad Tohari illustrates significantly the life of Tayub in Javanese rural village. How the initial condition of a village which was poor become the main reason of the emerging of Tayub dance is described in detail in the first paragraph of this novel.

\begin{abstract}
“Sepasang burung bangau melayang meniti angin berputar-putar tinggi di langit.Tanpa sekali pun mengepak sayap, mereka mengapung berjam-jam lamanya.Suaranya melengking seperti keluhan panjang.Air.Kedua unggas itu telah melayang beratus-ratus kilometer mencari genangan air.Telah lama mereka merindukan amparan lumpur tempat mereka mencari mangsa; katak, ikan, udang atau serangga air lainnya.Namun kemarau belum usai.Ribuan hektar sawah yang mengelilingi Dukuh Paruk telah tujuh bulan kerontang.Sepasang burung bangau itu takkan menemukan genangan air meski hanya selebar telapak kaki. Sawah berubah menjadi padang kering berwarna kelabu. Segala jenis rumput, mati.Yang menjadi bercakbercak hijau di sana-sini adalah kerokot, sajian alam bagi berbagai jenis belalang dan jangkrik.Tumbuhan jenis kaktus ini justru hanya muncul di sawah sewaktu kemarau Berjaya" (Ronggeng Dukuh Paruk, 1992, p. 1).
\end{abstract}

The illustration of poverty living is picturized clearly in the above citation. Desa Dukuh Paruk that is dry with no water to farm and harvest should become the clear picture of a poverty living. Even, it is illustrated in the story that there is not even a drop of water can be seen in hectares of rice field had by the village of Dukuh Paruk. The representation of literary work in capturing a real life does not only describe the concrete reality, but also explore the emotional and mental perspectives that sometimes do not seem real in the real world. As argued by Hogart (1960, p. 150) that literary works present a portrait of social life in a comprehensive way. Through literary works, a social life can be illustrated as a whole.

Literature is able to represent the way of human attitude and behavior in social life (Bonald, 1840). Further, Swingewood explains that sociology should be a tool to explore a literary work, presenting 
what is implicated and what is about to explain. Poverty in Tayub performing art's area is not only related to its geographical factor but also to the local belief and myth.

Kemelaratan di sana terpelihara secara lestari karena kebodohan dan kemalasan penghuninya. Mereka hanya puas menjadi buruh tani. Atau berladang singkong kecil-kecilan. Bila ada sedikit panen, minuman keras memasuki setiap pintu rumah. Suara calung dan tembang ronggeng menina-bobokkan Dukuh Paruk. Maka benar kata Sakarya, bagi orang Dukuh Paruk kehidupan tanpa calung dan ronggeng terasa hambar. Calung dan ronggeng pula yang memberi kesempatan mereka bertayub dan minum ciu sepuas-puasnya (Ronggeng Dukuh Paruk, 1992, p. 86).

From the citation, we know that poverty in the village where Tayub is developed is actually caused by the stupidity and laziness of people living in it. For them, soil fertility and harvest can only be received by offerings, ritual, and Tayub performance. There is no people working hard to fertile their soil or do some attempts to improve their crop yields. People living in this village believe that their ancestor will help and provide them with harvest. It is seen from the following citation.

...membiarkan Dukuh Paruk tetap cabul, kere, dan dungu adalah bertentangan dengan misi utama kemanusiaan itu sendiri. Mengajak Dukuh Paruk menyelaraskan diri dengan selera Ilahi adalah mengajak orang-orang di sana membersihkan diri dari koreng, dari ciu, dari omong cabul, dan dari kesewenangan berahi. Dan yang terpenting, memperkenalkan kepada mereka siapakah Penguasa Sejati kepada siapa mereka harus bertata karma sebaik-baiknya. Mereka harus bisa membaca huruf dan membaca alam. Mereka harus bisa menggunakan pikir selain rasa. Dan mereka harus percaya bahwa kemelaratan sama sekali tidak bisa menjadi nilai kebanggaan (Jantera Bianglala, 1992, p. 86).

From this citation, we can see that villagers still held strong belief towards ancestral tradition. A challenging geographical condition actually can be improved through a better irrigation system. However, stupidity and mystical spiritual values have covered this possibility. In the context of Tayub performance, on the other hand, the imperishable Javanese mystical spiritual values have given positive impacts. Javanese philosophy which emphasizes feeling, has made Tayub to have high and strong art senses on togetherness that become the root of life of villagers. Therefore, the shift in this formation can bring negative impact to the natural essence of Tayub performance.

Based on the interview done to the villagers, head of Department of Culture, and Tayub's artists, information can be collected regarding to Tayub which is contained with custom and myth that still develops strongly in the life of society. Even, in this modern era, the attitude of being obedient to the ancestors is still strong among elders. Nevertheless, modernization has surely given dramatic change towards the development of this performance. This exploitation also affects in the thinking pattern and values of customs that are melted and be a part of society's life. The Javanese philosophy "slow but sure" is considered inappropriate to the fast movement in modernization era. Therefore, all things are graded in an instant and superficial way, and are analyzed in a shallow way. Tayub performing art is not seen from its dance philosophical essence anymore, but more to the appearance of its attractive output. Tayub performance is created as interesting as possible for promotion purposes. "Saweran", or giving money to the dancers while dancing, or "lempar sampur', holding cloth to some guys to make them do the dance with the dancers, that used to be the characteristic of Tayub is also currently only used as complement without any essence of understanding the real meaning of Tayub.

The changing made to the Tayub performance that is done through various exploitation can not be hindered. Besi- 
des the changing on society's condition, the village environment condition where Tayub is performed also experiences change. The village which had less water is now dissapeared. Modernization gives easiness in terms of transportation, irigation system, and education. Eventhough the village hasnot been totally free from poverty, that can be seen from the local people's housing and their occupation, however the life of the local people has been better. Tayub dance performance which became a main occupation and a helper for the society has turned into a usual dance performance. Numbers of young people who had been studied and received proper education has finally developed this type of performing art into a fresher and worthwatching performance. In this modern era, young generation learns Tayub through dance learning in dance school. The spontaneous essence of Tayub in presenting the talent of a dancer now has been replaced with dance learning based on an ordered and managed procedures and formation, so that talent as it is described in novel entitled Ronggeng Dukuh Paruh in this modern era has been slowly dissapeared.

Di pedukuhan itu ada kepercayaan kuat, seorang ronggeng sejati bukan hasil pengajaran.Bagaimanapun diajari, seorang perawan tak bisa menjadi ronggeng kecuali roh indang telah merasuk tubuhnya.Indang adalah semacam wangsit yang dimuliakan di dunia peronggengan (Ronggeng Dukuh Paruk, 1992, p. $8)$.

Tayub art was initially impossible to be danced by all people. Only certain individuals are able to perform Tayub. These people are given with "indang", special spiritual ability, to perform Tayub. This condition has been changed in this modern era. Tayub performing art is able to be danced by all dancers without needing to obey the custom's rules.

Tayub in modern era is more directed to an entertainment performance that gives more emphasis on the outside appearance and show-time effectivity. Even though in several regions, Tayub is still performed for traditional ceremonies and rituals, however the philosophical structure of art has shifted from its initial pattern. Modernization has significantly impacted the Tayub performance, since the modernization in this type of art does not only exploit the dance structure but also give impact to the shift of society's value and culture. Bahrein (1977, p. 55) states that the occupation system, the belief system, and the society system are able to shift because modernization that has existed in a nation. The fixed rules of tradition, myth, and belief are slowly disappeared in this modern era. Tayub performance turns into a more dynamic, effective, and efficient dance. It is clearly picturized the life of Javanese rural society which has become faster, individual, and free from the local tradition.

In Tayub Rinenggo performance in Taman Budaya Yogyakarta, a significant change can be seen from the persperctive of dance movement and music accompaniment. Tayub Rinenggo in Taman Budaya Yogyakarta shows more creative and energic dance movements. From the perspective of music accompaniment, it is more dynamic. In one session of interview with the choreographer of Tayub Rinenggo, it was explained that the dance movement performed in Tayub Rinenggo has been modified so that it is able to merge with the dance movements. He was inspired by Banyuwangi gamelan which is sounded dynamic (August, 2016). The making of dance, that is packed for vacation purposes, indeed needs creativity that may trigger the audiences' interest to watch and enjoy, as has been delivered by Patmawati (2006) that:

Dance as a performance is a dance performed for the purpose to give aesthetic experience to the audience. The dance is performed so that it can be appreciated as an artwork and really entertain the audience. Because of that, dance as an art performance needs more serious observation as an artwork than just a mere entertainment. 
Creative work in art indeed needs creative hands of the artists who always pay attention to the aesthetic beauty. Good techniques can be cultivated from local genius as well as other aspects, as explained by Yanuartuti (2016),

\begin{abstract}
Art is a product of any art performances that contain aesthetic characteristics. Art was born out of a deep feeling of its creator. Since the beginning, art was born from the hands of creative artists through a spiritual process and a profound thought. In the middle of ongoing era development, a modern creative touch technique was needed. Touch technique and creative process of traditional performance can produce creative art products containing local wisdom that can be enjoyed by the modern people.
\end{abstract}

The creative process done by one of interviewee, the head of dance school and choreographer of Tayub Rinenggo dance, is a creative process that attempts to answer the challenges of time for the tradition to be able to be enjoyed by modern people.

\section{CONCLUSION}

Exploitation done in Tayub performing art is indeed brings impact to the life of Javanese rural society, not only from the dance perspective, but also to the mindset of the local people. Exploitation of Tayub performance which attaches modernization, has made this dance becoming simpler, more entertaining, and pleasant. At the same time, it has also changed the mindset of local people become shallower and pleasure-oriented, while slowly leave the tradition that has been built by their ancestors. This exploitation also gives impact to the mindset and custom values that melt and be a part of the society's life. The philosophical Javanese concept of alon-alon asal kelakon, or slowly but sure is considered improper to the fast movement of modernization.

\section{REFERENCES}

Bahrein. (1997). Sosiologi Pedesaan (Suatu Pengantar). Jakarta: Raja Grafindo Persada.

Hogart, R. (1975). Contemporary Cultural Studies: An Approach to the Study of Literature and Society. In Malcolm Bradbury and David Palmer (ed.) Contemporary Criticsm. London: Edward Arnold.

Pradhana., E. K. A. (2013). Fungsi Seni Tayub dalam Masyarakat di Dusun Ngrajek Desa Sambirejo Kecamatan Tanjung Anom Kabupaten Nganjuk. Media AntroUnair, 2(1).

Minsarwati, W. (2002). Mitos Merapi dan Kearifan Ekologi. Yogyakarta: Kreasi Wacana.

Pratamawati, E. W. S. D. (2016). Malang Mask Puppet Presentation Structure Arrangement of the Story Rabine Panji as Cultural Tourism Commodity in Malang Regency East Java. Harmonia: Journal of Arts Research and Education, 16(1), 66-74.

Soekanto, S. (1994). Sosiologi Suatu Pengantar. Jakarta: Raja Grafindo Persada.

Suharto, B. (1999). Langen Tayub, Pertunjukan dan Ritus Kesuburan. Bandung: Masyarakat Seni Pertunjukan Indonesia (MSPI).

Tohari, A. (1988). Lintang Kemukus Dini Hari. Jakarta: PT. Gramedia.

Tohari, A. (1992). Jentera Bianglala. Jakarta: PT. Gramedia Pustaka Utama.

Tohari, A. (1992). Ronggeng Dukuh Paruk. Jakarta: PT. Gramedia Pustaka Utama.

Widyastutieningrum, S. R. (2007). Tayub di Blora Jawa Tengah Pertunjukan Ritual Kerakyatan. Surakarta: Pasca Sarjana ISI Surakarta dan ISI Press Surakarta. Yanuartuti, S. (2016). Building Creative Art Product in Jombang Regency by Conserving Mask Puppet. Harmonia: Journal of Arts Research and Education, 16(1), 30-37. 